\title{
Article
}

\section{Anthropocene: new geological era or new biophysical.}

\author{
López Ortega, Jordi ${ }^{1, *}$
}

1 Universidad de Barcelona; Universidad Politécnica de Catalunya, jordi.lopez.ortega@upc.edu

* Correspondence: jordiortega@hotmail.com; Tel. 34.936.891.900

\begin{abstract}
The Anthropocene has created a new cartography where various discursive levels are intertwined. It unites two fields of knowledge: geology and anthropology. In the 19th century, Romanticism challenged the separation between natural sciences and spirit sciences. With the Anthropocene a geological era is established, but with an epistemological dimension: environmental catastrophes are not a passive "object", they become an agent of social and political change. Images of the world (Weltbild) turn nature into an animated whole that challenges the dual vision: observer and observed. There is no nature without "observer", nor geology without anthropology. The Anthropocene modifies the foundations of our view of the world where we had excluded life. This is how concepts such as symbiogenesis, homeostasis, etc., which make visible and try to explain phenomena that are otherwise inexplicable. The Naturwissenschaft by J.W. Goethe is a point of support, with all these ideas that develop in the 20th century and anticipate the Anthropocene term of the 21th century. While the concepts of "belief" and "science" continue to be sharpened, rehabilitating "old quarrels" around anthropology, cosmology, theology, etc. The dignity of man is at stake.
\end{abstract}

Keywords: Anthropocene, Noosphere, Biosphere, Morphology, Metamorphosis, Geophysiology

\section{Introduction}

The term Anthropocene was coined in 2000 by Paul J. Crutzen (1933-2021). It is no coincidence that the term was coined by an atmospheric chemist who won the Nobel Prize in 1995 with research into the chemical composition of the atmosphere. At a conference in Cuernavaca (Mexico) he heard "we are in the age of the Holocene", and exclaimed: "No! We are no longer in the Holocene, but in the Anthropocene!" (Arias-Maldonado, 2018).

The term Anthropocene is not accepted by the community of geologists. For their acceptance they created "The Anthropocene Working Group" (AWG). The group seeks "evidence" of man's transformation of the biosphere and atmosphere. The magazine Nature (Jones, 2011) claimed recognition of the Anthropocene by "The International Commission on Stratigraphy (ICS)". Two decades later, the Anthropocene (which claims that being human has become a geological force) jumps from the natural sciences (chemists, physicists, geologists, climatologists, etc.) to the social sciences (anthropologists, archaeologists, sociologists, philosophers, etc.). Today the Anthropocene is used regularly by different disciplines, but is far from a "transdisciplinary and holistic" approach (Hamilton, 2016).

\section{Anthropocene: geological era changes and gnoseological change}

Eugene F. Stoermer (1934-2012) in the eighties used the term Anthropocene. He studied ecological changes in the great lakes resulting from human activity (Stoermer, 1984). The term Anthropocene is popularized from the year 2000; after the aforementioned conference in Cuernavaca in which Paul J. Crutzen proclaims a change of era. Together with Eugene F. Stoermer they publish an article in which they consider that the homo sapiens it is no longer just a historical actor, it is a geological actor. The article by Paul J. Crutzen and Eugene Stoermer has two distinct parts; a first establishes a "a period of time" and an "epistemic tool" (Arias-Maldonado, 2015:126). 
Let's examine it in parts: (1.1) a new geological era and (1.2) the new scientific paradigm or gnoseological change.

\subsection{A new geological era}

The first describes something very specific: how human activity alters the nitrogen cycle: "the earth's surface has been transformed by human action; more synthetic nitrogen (applied as fertilizer in agriculture) is now fixed synthetically and applied as fertilizers in agriculture than fixed naturally in all terrestrial ecosystems. (Crutzen, Stoermer: 2000:17-18).

It has been pointed out that with the appearance of agriculture man begins to alter the biosphere. The capacity of collector hunter societies to alter was less than in agricultural societies. Cities, with their increase in population, reduce crop rotation. The current challenges of agriculture focus on the use of inorganic nitrogen fertilizers and the development of agrochemical that interferes with the nitrogen, carbon and phosphorus cycle (1.1.1.). The IAASTD report (2009) is relevant: Agricultures at a Crossroad supported by six $\mathrm{UN}$ agendas and representatives of governments and civil society; it is unequivocal: the current model of food production is unsustainable. Agrochemical is based on standardized monocultures (developed in 1.1.2). Agroecology makes an early critique of the "Green Revolution" that differentiates organic nitrogen from inorganic (developed in 1.1.3). What promised to end hunger on the planet has not only been a huge failure, which shakes the conventional discourses of science, but also generates new problems that demand new paradigms (developed in 1.2).

\subsubsection{Challenge in agriculture.}

Agriculture is presented as a human activity that impoverishes soil fertility. We consider, in the same way, that the activity of the vegetable "depletes" the nutrients of the soil. We have had agriculture for more than 40,000 years, and plant life thousands of years ago, according to the "cycle of life". For a century we have created a huge problem: 821 million people suffer from hunger, another 2,200 million from malnutrition: from diabetes, obesity, cardiovascular diseases, vitamin deficiency and trace elements. Between 1961 and 2019, "the use of nitrogen fertilizers" increased by 800\% (IPPC, 2019: 439). Annually, 128 million tons of nitrogen from the atmosphere (with FAO data from 2008) are transformed into synthetic fertilizers to produce food. To produce this inorganic nitrogen, 5\% of natural gas is spent (EU Agricultural, 2019). It adds to the nutritional problem, an energy and climate problem that did not exist before. One calorie of food requires 10 calories of fossil energy - not counting machinery, transportation, etc. (Valero, 2019). A century ago the relationship was inverse: 10 calories of food for one energy calorie. Part of that nitrogen pollutes the atmosphere: nitrogen dioxide; another part pollutes the rivers and ends up in the oceans: 14 million tons (Rockström, et al, 2009). This causes the oceans to have hypoxia, aggravated by eutrophication: excess nitrogen, phosphorus and organic matter and loss of oxygen (Duarte, Pardo, 2009:95).

There are those who place the problem in human activity. Others in the economic. Others blame demographics. There is no shortage of those who, in the face of this, defend an ecological "apartheid". Agriculture, guided by political economy, is concerned with the productivity of the land, not what it is to produce nutritious food. This paradigm is the subject of harsh criticism by IAASTD (2009). Ecological economists concerned about sustainability work indicators such as: energy cost, loss of biodiversity, etc. Paul Ehrlich (1932-) popularized the term "carrying capacity". Leopold Pfaundler (18391920 ) pointed out that the carrying capacity of the sum of territories is greater than the sum of autarchic territories. 
In the last century, the use of synthetic nitrogen fertilizers has interfered with the organic nitrogen cycle (Mulvaney, Khan, Ellsworth, 2009). It causes a loss of fertility. "1,310 million people trapped in degraded agricultural land, it is estimated that they produce an annual loss of 24,000 tons of fertile soil (Valero, 2019:133)." It is a "global pandemic" of chemical pollution, soil acidity and microbial loss (OECD/FAO, 2020).

Nitrosamine, which is transformed into mineral nitrogen, is a carcinogenic compound. Every year nitrogen and mineral phosphorus are added to the environment, which depletes soil carbon, reduces the microbiological capacity to fix nitrogen and unbalances the diet of plants increasing parasites and pests. The answer is polarized between those who see the solution in spraying the earth with synthetic nitrogen (1.1.2) and those who bet on stimulating, with agroecology, the organic nitrogen cycle (1.1.3). We cannot ignore that phosphorus mines suffer a progressive depletion that leads to the collapse of the current global agricultural model (Valero, 2019:131).

\subsubsection{Agrochemical}

Justus von Liebig (1803-1873) is the father of agrochemical. He advocated the "scientific" method for agriculture. In "Die organische Chemie" (1840) the "replacement law" is formulated (Gesetz der Ersatzes): to prevent loss of fertility, nutrients extracted from the soil by plants need to be replaced to maintain metabolic interaction (Stoffwechsel) and proposes that they be restored by the contribution of inorganic nitrogen.

Justus von Liebig criticizes British agriculture for its "alignment of crops". He considers them to be based on an "irrational method" (Foster, Clark, 2018). For Justus von Liebig every plant, without exception, depletes the soil. Karl Marx (1818-1883) in Das Kapital he supported the theses of Justus von Liebig: in his criticism of capitalist agriculture for squandering the "forces of the soil" (die Bodenkraft verschleutert) going on to criticize the dilapidation of the "labor forces" (Marx, 1985:821).

Karl Marx's reception of Letters on modern agriculture of Justus von Liebig has seduced not a few Marxists (Foster, 2000). But its sowed discord between agroecology and Justus von Liebig's "ecosocialist project" based on agricultural chemistry. Agriculture for Justus von Liebig is not limited to the postulates of political economy: more important than the relations of production is the metabolism between energy and nutrients. But it places the emphasis on chemical-physical components, and not on something of utmost importance: plant life that interacts with animal life in a mutual rapport (Steiner, 2010a:27).

The use of inorganic nitrogen in agriculture has increased exponentially over the last century. The architect is Fritz Haber (1868-1934) who discovered how to narrow the cycle of synthetic nitrogen by creating fertilizers that could be added directly to the soil (Duarte, Pardo, 2009:53). The German chemical industry had surplus nitrogen that it used to make explosives and, following the theory of Justus von Liebig, used it in agriculture. In 1918, Fritz Haber won the Nobel Prize in Chemistry. It was a controversial decision; the committee recognized that chlorine gas killed and mutilated hundreds of thousands of soldiers (in contravention of the Hague Convention of 1907); however, it considers that organochlorines to be an achievement in intensifying food production. The impact on health, through the food chain, led to them being banned. We see this promiscuity between agrochemicals and military industry. 


\subsubsection{Criticism from agroecology}

The chemist and naturalist Ragnar Berg (1873-1956) (1930), in the decade of the 20s, considered that foods produced with synthetic fertilizers are organoleptically inferior than those produced with organic fertilizers. What are offered to us as fresh and healthy foods have been harvested with the postulates of Justus von Liebig and are therefore negative foods for health (Piulats, 2017:222-223). For Rudolf Steiner (1961-1925) (2010a:135) it is "mere stomach fillers" (bloßen Magenausfüllungen) without "nutrient strength" (Nährkraft). Agroecology distinguishes organic fertilizers from synthetic fertilizers, nitrites and nitrates with a low nutritional quality and high deficit of vitamins and trace elements (Kirchfeld, Boyle, 1994:148).

The busy ecology with "carrying capacity" measures CO2 emissions, energy, biodiversity loss, but does not care about how light works in the sulfur and phosphor. (Steiner, 2010:62). Farmers concerned about the developmental and consequences of agrochemical asked Rudolf Steiner (2010a:16) for a lecture series in 1924. At these conferences, I lamented the indifference that farmers pay to how nitrogen is prepared: where it comes from, whether it was nitrogen from the air (dead or inorganic) or live nitrogen (organic), etc. The earthly laws are winning the game to the solar laws. There is a symbiosis between the plant system and the solar system: the forces of life are in retreat in favor of the forces of gravity.

In the Anthropocene it refers to how the fixation of fertilizers in the soil, which is not more than a century old, causes a fracture in the metabolism of life. The massive introduction of synthetic nitrogen into agriculture wasted in the organic nitrogen cycle (Weizsäcker, Wijkman, 2019). We can compare it to the extinction of pollinators. No less terrible is the extinction of the biological community that interacts in a biotic and abiotic way in the soil. Without it we can no longer feed ourselves (Lehman, et a, 2015). Soil fertility is the most important intergenerational resource on which our survival as a species depends and turns out to be the underrated resource (Weizsäcker, Wijjman, 2019).

It is up to us to develop an agriculture that improves, in the long term, the fertility of the soil. It is quite different from an agriculture based on an increase in production in the short term. The challenge, in the 21th century, is to address a change of direction that prevents the collapse of the global food system.

\subsection{The new scientific paradigm (new epistemological paradigm)}

Paul Crutzen and Eugene Stoermer (2000) mention pioneers who anticipate the concept of the Anthropocene. They are long-silenced authors. Georg Perkins Marsch (1801-1882) states, in his work "Man and Nature" published in 1864, a link between anthropological and nature; points out that human activities have a transformative power of the morphology of the earth's surface. Antonio Stoppani (1824-1891), priest, geologist and paleontologist, describes human activity as a "new telluric force which in power and universality may be compared to the greater forces of earth"; in 1873 he used "the Anthropozoic era".

\subsubsection{Noosphere and biosphere}

The Russian geologist Vladimir Ivanovich Vernadsky (1863-1945) who published in 1926 should be highlighted The Biosphere (Vernadsky, 1998). This term biosphere is inspired by Johann Wolfgang Goethe (1749-1832), Jean-Baptiste Lamarck (1744-1829), Alexander Humboldt (1769-1859), etc. More than by The Biosphere, V.I. Vernadsky is known by Noosphere. Aristotle (384 BC-322 BC) uses the term voṽ $\varsigma$ or vóo ("mind"). V. I. 
Vernadsky realizes that the chemical composition of the Earth's crust presents alterations in composition that are not explained according to the laws of physics, nor chemistry. Living matter arises from the processes of transforming the sun's radiant energy into organic matter through photosynthesis. It is a unique mechanism compared to that of terrestrial bodies. The distinction between living matter and inert matter begins, although they include each other, and an intelligence is incorporated (noos). "The noosphere is the third in a succession of phases of development of the Earth, after the geosphere (inanimate matter) and the biosphere (biological life)" Geosphere (inanimate matter) and the Biosphere (biological life)) (Müller, 2020::354). The crust is the region of the biosphere, its epidermis, where life sits; this makes it possible to affirm that no living organism has been engendered by inorganic matter. If life disappeared from the Earth's crust, so would the cosmic processes.

The hundreds of minerals resulting from chemical processes that occur in life, without it, would disappear. Mineral elements would be grouped differently. In 1875 the Austrian geologist Eduard Suess (1831-1914) (1875:159), in Die Entstehung der Alpen, establishes that the speed of the Earth's rotation is the same, 33,100 centimeters/second, with which the energy of the bacteria circulates. It is not about properties of organisms, but also reflects planetary and cosmic phenomena. Eduard Suess thus extends the boundaries of the descriptive natural sciences and creates theoretical systems that encompass the whole. The philosopher, Jesuit, paleontologist and professor at the Catholic University of Paris Pierre Teilhard de Chardin (1881-1955) had already developed, shortly before, the notion of "noosphere" taken by Vladimir Vernadsky. The "Gaia hypothesis" of James Lovelock (1919-2019) and Lynn Margulis (1938-2011) considers that physical and chemical conditions have been and are still being adapted to the needs of life itself. It is similar to what Vladimir Vernadsky maintains. Here we point out that oxygen and other biogenic gases (CO2, NH3, and H3S) involved in life are products of life itself (Piulats, 2018:110). A postulate in contradiction with the official paradigm of science.

\subsubsection{The mystery of the atmosphere}

The Atmospheric chemists discover that the Earth's atmosphere is not the result of geological processes, but of biological processes. In the molecules involved in life there are only six elements: carbon, nitrogen, oxygen, hydrogen (in ancient times; earth, water, air and fire) and, to a lesser extent, phosphorus and sulfur. It is inexplicable, from the conventional scientific paradigm, the constant equilibrium for billions of years in the atmosphere of $78.089 \%$ nitrogen and $20.946 \%$ oxygen (Piulats, 2017:67). Researchers found that in the Cretaceous there was 35\% more oxygen in the atmosphere. If the percentage of oxygen were to fall, nothing would burn, if it increased by $2 \%$ the fires would be devastating. The surprise for Andrew G. Thomas was to discover that in the Cretacean there was also more nitrogen: the balance was maintained (quote, Lovelock, 2006). If we extract nitrogen from the air of a room in which a person is located, it is immediately replenished and balance is restored (Steiner, 2010a:71).

Materialistic science considers nothing more than the physical substrate of the atmosphere and forgets the spiritual (Steiner, 2010a:67). It is surprising how little or no interest in life is ubiquitous in the biosphere and in the balances that depend on life, notes Lynn Margulis (1986:108), in terms of information and order. It is also a source of negative entropy (Lenton, et. al, 2020). Something similar happens to agriculture; it focuses on the plant and forgets about the soil; the ploughing of the earth destroys the fertility of the soil by penetrating it the sun and the oxygen that kills microorganisms that are the essential part of the organic nitrogen cycle. It is an aberration to destroy the capital of the earth and it also causes massive methane emissions. 
J.W. Goethe, on the other hand, finds that mechanistic thinking cannot explain barometric oscillations: the atmosphere compresses (the pressure increases) and dilates (the pressure decreases) giving rise to air currents that regulate the temperature (by increasing or decreasing the amount of humidity). In this ebb and flow, he rules out an "extraterrestrial force" acting. His hypothesis is that of an Earth alive. He compares it "with the inspiration and exhaling of an organism" (mit dem Ein- und Ausatmen eines Organismus) (Steiner, 1990:201). These ideas of J.W. Goethe have inspired, in the 20th century, from the feedback loop theory of Ludwig Bertalanffy (1901-1972), the homeostasis of Walter Cannon (1871-1945), the procedural philosophy of Alfred North Whitehead (1861-1947), the self-asserted systems of Ilya Prigogine (1917-2003), Manfred Eigen (1927-2019), Heinz Foerster (1911-2002) and Humberto Maturana (1928-), to the Anthropocene of Paul Crutzen and the geophysiology of James Lovelock (2006).

\subsubsection{Symbiogenesis between animals and plants}

Humans (and other animals) inhale oxygen and nitrogen and exhale carbon dioxide (CO2), excrete nitrogen in the form of urea (ammonium and carbon dioxide). The Darwinist theory of evolution, if true, would have endowed us with more efficient physiology. If uric acid were exhaled, as we do with CO2, with breathing we would avoid a high consumption of water (4 liters/100 $\mathrm{g}$ of urea) and a high energy expenditure (379 kilojoules/100 g of urea) (Lovelock, 2006). A waste of water and energy. In respiration, nitrogen drags oxygen into the encounter with carbon to transport it outward (exhaling) in the form of carbon dioxide (Steiner, 2010a:69). The plant does not have that ability to remove carbon, so it develops dense forms (Steiner, 2010a:65).

Darwinian evolution is incompatible with the Gaia hypothesis (Lovelock, 2006). A selfish gene would have favored a mutant gene that excretes urea to save water and energy. The response of the biochemist, of a teleological nature, is that we excrete urea instead of nitrogen because it is toxic. James Lovelock's reaction would be, "explain it to bacteria." A symbiogenesis with bacteria, which breaks down nitrogen, would have been as good or better a solution than metabolizing urea. If we were more efficient and exhaled inorganic nitrogen, plants would have nothing to nourish themselves from and us to feed on (Lovelock, 2006).

The diversity of living organisms is the result of the rapport of very few elements (N, O, C, H, S, P); its composition is not randomly determined by chemical structure, but is established "in an orderly and patterned manner" (Margulis, Sagan, 1986:51). J.W. Goethe's morphological composition is based on science that studies "non-physical fields". In the 20th century, from this concept, from complex catalytic networks to feedback loops were developed. The development and maintenance of life is attributed by Rupert Scheldrake (1942-) to the fields "morphogenetic" or "morphic resonance" (Capra, 1986). The geometry of the minerals is centrifugal: it fills the space subjected to gravity; organically there is a polarity between centrifugal and centripetal that reminds us of breathing: to inspire and to expire. There the "formative forces" overcome and are subtracted from gravity. Perhaps the question of the origin of life is ill-considered. Nobel Laureate Francis Crick (1916-2004) uses the term "panspermia": the hypothesis of the origin of life is in extremophile organisms (Peinado, 2019). It would not be unreasonable to claim that 'we are stardust'. NASA has found RNA components in meteorites (Furukawa, Chikaraisch, 2019). Oxygen, discover James Lovelock and Lynn Margulis (1974), is a molecule involved in life that is not inert in nature. There, the mystery. 


\section{The threatened epistemological division}

Microbiology developed the concept of symbiogenesis from studies of bacteria networks with self-regulation capacity (Aanen, Eggleton, 2017). Illustrious precursors such as. Gustav T. Fechner (1801-1887), professor at the University of Leipzig, physician, philosopher, physicist and naturalist, understand the cosmos as an animated whole in Ideen zur Schöpfungs- und Entwicklungsgeschichte der Organismen (1873). Gustav Fechner (2011) uses the term psychophysics to also consider that the stars have life. Heinrich Heine (1797-1856) (1969-1976:VI, I, 479) understands the philosophy of the spirit of G.W.F. Hegel (1770-1831) as a process in which "God becomes self-aware in man". It proposes this synthesis between the party of flowers and nightingales to twin sensualism and spirituality, social justice and beauty, Jewish asceticism and hellenism that Hegel, Hölderlin and Schelling had dreamed of (Habermas, 2013).

\subsection{The loss of meaning of the world}

The separation between natural sciences and social sciences is a wall that prevents ecological catastrophe from becoming an agent of the metamorphosis of the world (Beck, 2016). The origin of this gap between the "world of life" and the "objectified world" is located at the moment when the axial reformers allowed to build the great coherent and transmissible systems of knowledge. It is one of the greatest cosmological revolutions. The whole, encompassing the "world of life" and the "objective world," is separated. The Babylonian astrologers, the Egyptian geometers and mathematicians, etc., unlike our astrophysicists, mathematicians, etc., had no worse knowledge, the great systems of knowledge were caught hand in hand with everyday practices. In Aristotle, normative arguments still went hand in hand with empirical reflections (Habermas, 2006).

Ulrich Beck (2015) focuses the analysis of the Axial Age (Achsenzeit) in disputes between the "moral divine order" and the "social and political (earthly) order"; the spiritual elites intended to assert their yardstick of the transcendental order in the temporal order. And since then the "homo sapiens" and the "homo ritual" took different paths.

In the 12th century the explosive conflict between the discourse of revelation and the discourse of reason erupts. It is a conflict between two spiritual currents. Opposing concepts are sharpened: science and belief. The Arabism reception of Aristotle had excluded the possibility of discovering in nature a "divine manuscript". Christian scholasticism finds in nature, through Aristotelian ontology, that manuscript (Lutz-Bachmann, Fiora, 2008). Scholastic nominalism will pave the way for an empirical and impartial contemplation of nature that leads Rene Descartes (1596-1650) to separate the "res-cogita" and the "res-extensa": the natural sciences (the experienced) versus cosmology or sacred history (the lived). Friedrich Nietzsche (1844-1900) warns, in a fragment entitled "Hinfall der kosmologischen Werten" (1887-1888), of a "devaluation of the supreme values" (der Entwertung der obersten Werte). In it designates "den Hinfall der kosmologische" Werte" (the expiration of cosmological values) as noted by Martin Heidegger (1889-1976) (1961:5558).

\subsubsection{The meaning of evil}

We have contextualized the debate about the meaning of evil. Jürgen Habermas (2019:361,546) draws the consequences of the dispute in the early centuries between the Neoplatonism of Celsus (2th century) and Plotinus (205-270) versus the early Christians, Tertullian (160-220) and Augustine of Hippo (354-430). It is more than just a theological or philosophical dispute. Jewish mysticism and Protestant mysticism, which have in Isaac Luria (1534-1572) and Jakob Böhme (1575-1624) two of their highest 
representatives, formulate a theogony and cosmogony in which God is exiled to the darkness of his own foundation without foundation: God becomes his other and nature extends into God (Habermas, 1963). Hermetics and agnostics agree that man had descended from the spiritual world. But, while for Christians, Hermetics and kabbalists it is a "leap", for agnostics a "fall". The body, for agnostics, is a prison from which the spirit has its only salvation in escaping.

\subsubsection{Manichaeism and metamorphosis}

Hermes Trismegisto, asked by Asclepius about why possess a body, replies that the body allows the spirit to take care of creation (Lachman, 2013). More than a geological time we fix an anthropological time. But it is important for geological evolution. We have the inner gaze of Buddha (the gospel of Luke), the look at the cosmos of Zoroaster (the gospel of Matthew). These two currents come together in Christianity to rejuvenate them (Habermas, 2019:361).

There are two approaches to the problem of evil. Pelagianism refuses to admit that evil cannot be eliminated from the earth by human effort (Riechman:160). Manichaeism, on the other hand, does not suppress evil: darkness must be redeemed by itself. Man's task is to send that "spark" into darkness so that "evil" may be metamorphosed into "good." Jorge Luis Borges (1899-1986) in "The Rose of Paracelsus" puts in the mouth of Theophrastus Bombast von Hohenheim: "Do you think that divinity can create a place other than Paradise? Do you think the Fall is nothing more than ignoring that we are on Paradise?" All nature is at the service of man (an "anthropocentric" hypothesis); but, he adds: "no substance can be used without great art... the human being is to transform it" (Paracelsus, 1965:544). Celsus, famous for his attacks on Christianity, as well as neopagans and agnostics, believes that the world was created by a kind of idiot God; we are spiritual beings trapped in a physical and evil cosmos.

The response to the planetary ecological crisis, for John Gray (2015) in The Soul of the Marionette, consists of returning to those older religions when the problem of evil did not exist; then we lived in a world that contained light and darkness, creative and destructive forces, good and evil. Evil, for John Gray, has its origin in Zoroastrianism, Manichaeism, Rosicrucians, Cathars, etc. He finds in the scientific revolution, even if he denies Christianity, a byproduct of magic, alchemy, etc. It does not leave out Issac Newton (1643-1727) who believed in numerology and sought hidden meanings in the Bible. Before Bodhisattva adopted buddha's body there was no guilt; man, if anything, was possessed by evil. Jesus, influenced by Zoroastrian ideas understands life as a war between light and darkness, between good and evil.

\subsubsection{Agnostics against Gnosis}

James Lovelock agrees with John Gray not only in his criticism of Christianity and humanism, but also in his faith in progress and in a human being who is too fragile to accept the truth. According to him, "sustainable development" is that faith to be eradicated and replaced by, the inevitable, "sustainable withdrawal" (Lovelock, 2006). A previous step to discussing anthropological and cosmological pessimism is to let geologists, biologists, oceanographers, etc. speak; and, in a second moment, points out Jorge Riechmann (2017:261), debating this pessimism from Giacomo Leopardi (17981837) or Arthur Schopenhauer (1788-1860), etc.

It is not spoken in scientific terms when John Gray (2003) blames humanistic and Christian mental infrastructures to add that men are ill-conceived and ill-made creatures (Gray, 2015). He agrees with the sociologist Lewis Mumfort (1895-1990) who contrasts 
the irrationality that runs through human history with the wisdom and rationality of the animal. In his work The Myth of the Machine (Munfort, 1971) reveals, in human evolution, a chronic predisposition towards error, evil, exorbitant fantasies, etc.

John Gray, says Gary Lachman (2013); it does not argue, it simply asserts. Take advantage of any mention of the human being to lower the fumes. Walter Benjamin's (1892-1940) $(1980,698)$ criticism of progress in his writing is very different. Über den Begriff der Geschichte, con the view that the SPD's "Gotha program" is a "secularized resurrection of Protestant labor morality"; from where fascism will later develop. Walter Benjamin in 1921 acquires the Angelus Novus of Paul Klee (1879-1940). Describes as The Angel of History ("Der Engel der Geschichte") is pushed, inexorably, into the future; but, at the same time, it turns its back: it looks to the past where ruins accumulate. Look to the past, as the hurricane, which we call progress, pushes you into the future (Benjamin: 1980, 697). Walter Benjamin, unlike John Gray, retains the hope that man can rebuild unity in a whole after the "breaking of vessels" (shevirat-ha-kelin, in Hebrew). The prophets of the apocalypse and those who preach faith in technological progress look to the past. Optimists and pessimists retain a "larval worldview", that is, they are not aware of their imminent metamorphosis, like the caterpillar, into a butterfly. They cling to the cocoon (Beck, 2016). They do not experience the tremendous transformation of their referential horizon.

\subsection{Guardians of the cosmos: Buddha, Zoroaster and Christ}

Isaac Luria (1534-1572), great kabbalist of the 16th century, considers that man has a task: the "tikún" -which translates to "repair" (Lachman, 2013). In the 19th century Soren Kierkegaard (1813-1855) considers that there was no such "fall", it was a "leap of faith" (Leap of faith). Faced with the idea that men are "cosmic repairers" the idea of human insignificance, of man reduced to nullity and, at the same time, turned into a geological force that is killing the Earth, makes its way. Man, as we shall see, is part of two worlds; the kabbalists who know that Adam (אדם) without the Elf is blood (Dam in Hebrew): Adam it unites the blue sky and the red earth. The idea of Tkkun suggests that when God creates the world "out of nothing," something does not go right; then, points out Isaac Luria, creates "of something" the man, which transmits the spirit to him. That is why for Isaac Luria and the Kabbalists, man can, thanks to the divine spark, stop the escalation of ecological destruction.

\subsubsection{East and West: Zoroaster and Buddha}

There are those who insist on seeing man as dust mops in the infinite universe, and gives him the condition of fallen angels whose only way out is "detachment", "asceticism", "meditation". A not wanting to know anything about the earthly. Man, on the other hand, houses within himself the eternal and infinite as suggested by the scientist, philosopher and mythical: Emanuel Swedenborg (1688-1772). It anticipates an idea, previously stated, that the universe intends to harbor intelligent life. Jorge Luis Borges describes it in a story: he worked in the mines, studied anatomy, aeronautics, etc., but refused the chair of Astronomy at the University of Uppsala because it was too theoretical a dedication.

Pindar sums up man's heroic task: "to become what he is". Today we are not so sure of an unlikely "technocracy" as José Ortega y Gasset (1883-1955) (2014:95) continues; considers that the technique cannot command, it is secondary, because the main thing of man is to make himself, to self-manufacture (2014:90). Today's man lacks imagination to know what he wants to be. Yuval Noah Harari, 2018) tells us that if we don't know what we want, it will most likely be easy for technology to shape our lives and decide for us. 
Life is not just about fighting matter; it is, fundamentally, struggle with the soul. The body and soul are things, the man, says Ortega y Gasset (2014:87), is "a drama". He contrasts the "Bodhisattva project": the one who "self-absorbed" within himself, and the "Gentleman's project": the one who "alters" himself in a struggle for life, exercising professions, etc. The Jesus of the line of Nathan, in the gospel of St. Luke and the Jesus of the line of Solomon (strains of David) come to unite and renew these two spiritual currents: the eastern technique of Buddha (563-483 BC) and the western technique Zoroaster (S. VII-VI BC); unite West and East (Ortega y Gasset, 2014:138). Buddha and Zoroaster represent that polarity between believing and knowing (Habermas, 2019).

The Anthropocene refers us to effervescent anthropological proposals. At the beginning of the 20th century we have the "cosmological anthropology" of Max Scheler (1874-1928), the "philosophical anthropology" or "anthroposophy" of Rudolf Steiner (1861-1925), the "existential anthropology" of Martin Heidegger (1889-1976), the "biological anthropology" of Helmut Plessner (1892-1985) and the "medical anthropology" of Viktor von Weizsäcker (1886-1957). Even Ernst Haeckel, a faithful disciple of Charles Darwin, far from suppressing teleology, makes it a supreme principle. Today, opposite trends prevail. It is not difficult to see the link between pessimism and misanthropic reflections. Sometimes the scapegoat for the ecological crisis is man himself, at other times, capitalism (or Capitocene), at other times, religion, as "the four horsemen of atheism" points out: Dawkins, Dennet, Hitchens, and Harris. Nor are science, creativity and wisdom spared.

\subsubsection{Mann without habitat: the uncanny (das Unheimliche)}

The Anthropocene is riddled with anthropological, theological, philosophical, sociological questions, etc. Every species has its own habitat, on the other hand, man lacks a habitat of his own: Earth for man is uninhabitable (ungewohnbar). That's why you need to manufacture (bauen) its habitat (wohnen). The man, for Ortega y Gasset (2014:209-210), "is not an animal... it is an intruder in the so-called nature. It comes from outside of it, incompatible with it, essentially misfit." Man, then, has to create an "inside", an "inner world", a "super naturalness", where he can take refuge from the weather. The animal lacks, says Max Scheler, that "chez soi". That "within itself" (Ortega y Gasset, 2019: 51). That is why man has that "eccentric" position, which Helmuth Plessner (1981) points out: We are Lieb (life) and Körper (body). We are part of the earth (red) and the cosmos sky (blue). Man, for José Ortega y Gasset (2014:209) "is on Earth, but does not inhabit wohnt-in it"; for, unlike other beings (mineral, vegetable and animal) "the earth is for man uninhabitable-unbewohnbar" (Ortega y Gasset, 2014:209).

Jorge Riechmann (2017) proposes us to live as good orphans, that is, to accept finitude and contingency. The gospel of John (16:4-12) refers to the "son of the widow" and the coming of Paracelsus, the being of the spirit. The West must learn from the East to look inward, to develop meditation. Buddha who looks inward and Zoroaster who looks at the cosmos, are two currents that unite and rejuvenate in Christianity (Habermas, 2019:361). Manichaeism seeks to inset evil gently. This does not mean that we have to resist evil. Evil becomes, as we saw in Ulrich Beck (2014), an agent of "emancipatory catastrophism". "Public goods" are "effects of goods but the positive side effects of bad". It is not easy to understand. We can observe it under three lenses: (i) the anticipation of a global catastrophe that violates the sacred (unwritten) norms of human existence and civilization; (ii) an anthropological shock and, (iii) a social catharsis. 


\subsection{Belonging to two worlds.}

The Axial Age leaves the world divided. Instead of a soul in a body we are a body endowed with life, it is that spirit that we do not know where to place. In the words of Ulrich Beck (1944-2015) (2016) we have the macro-level of the world and the micro-level of everyday life. Morphology tells us that there are planes and patterns that are not reduced to the material. The Anthropocene would come to fuse these two levels. Sociology that deals with the evolution of society and geology that deals with the evolution of the earth are now intertwined. The boundary between the organic and the inorganic is erased. This completely changes the way we see the world. Lynn Margulis points out that the six chemical elements that make up life combine according to one pattern (Margulis, Sagan, 1986).

The five substances $(\mathrm{S}, \mathrm{C}, \mathrm{N}, \mathrm{H}, \mathrm{O})$ involved in life combine under the laws of minerals: they have a different relationship than chemistry teaches us (Steiner, 2010a:75). Here the proposals that in recent decades make their way for an Earth seen as a gigantic "living" organism. It is far from the Darwinist view guided by selfishness and competition. Rocks, microorganisms, plants and other living beings cooperate, within the Gaia hypothesis. They establish a mutual interdependence, strengthen interactions and even have a certain altruism. It's a provocative hypothesis. It is not organisms that adapt to the environment, as Charles Darwin suggests, but it is the environment that adapts to make life possible.

\subsubsection{Physiology of the Earth.}

James Lovelock (2008) in The Guardian, in the face of the new optimism and technological arrogance, invites us to reflect. Geoengineering acts with the planetary climate in the same way that doctors did with diseases before the 40 s when we had few drugs on hand: morphine, quinine, aspirin and insulin and little was known about what the mechanism of action of these drugs was. The patients had two ways to deal with the disease: modern physiology (salutogenesis) or biomedicine (declaring war on germs: pathogenesis). Are we prepared, if we alter the planetary balance, to take on a permanent onerous task of maintaining the earth's homeostasis? If we use stratospheric aerosols launched from airplanes, as Bill Gates (2021) proposes, even if they are successful, sooner or later we would be faced with the problem of ocean acidity and so on. Then we will need other medicines. And so on. Modern physiology would recommend us to rely on the ability of the planet's natural self-regulation, that is, to reinforce salutogenesis and homeostasis. In the health emergency, says Richard Horton (2020), we follow "too narrow approaches" proposes to analyze the interactions between biology, environment, social equalities, etc.

The scientific approach prefers to divide and subdivide a problem, and to attend to interactions, to interdependence, in one word: it ignores the "context". The euro crisis was treated as a highly specialized subject. Political writers, from evening to day, warn of the secondary consequences of this crisis. The euro crisis is "contextualized" as a crisis of the very process of integrating European politics (Habermas, 2011). Monetary experts and elites reject these analyses as inaccurate and lacking in "scientific" rigor. Ulrich Beck (2016) pointed out how Draghi's "emergency policy" to save the euro bypassed all the monetary policy rules that the elites imposed by accelerating the process of European disintegration. We find here, as the euro crisis is also capable of metamorphosing into options for returning to national monetary systems. We are facing a revolution without revolution, a revolution without subject, a revolution instigated by the prevailing circumstances (Beck, 1988). 


\subsubsection{Metamorphosis and the Manichaean Faustus.}

The secondary consequences of the "public evils" that metamorphose into "goods" take us back to an "old quarter". It is an almost theological dispute over the meaning of evil. the happy of J.W. Goethe is Manichaeans: it does not mean that "good" and "evil" are mixed. Good has been hidden behind evil. Here arises the antagonistic position between Mani (216-277) and Pelagius (360-420); a British monk who accuses Augustine of Hippo (354-430) of, under Manichaeism influence, contaminating Christianity with pagan fatalism and "raising evil to the same level as God" (Riechmann, 2017:160).

Environmentalism, unlike the Anthropocene, presents the destruction of the planet as a strictly scientific issue. But it has theological and metaphysical derivatives. Manuel Castells (2009) identifies environmentalism as a mass of New Age, Neo-Paganism, countercultural, etc. There is no shortage of eccentric figures who proclaim: "Earth First!": they consider that we are all animals and human life is something irrelevant to the cosmos. Environmentalism, over and above the mass of tendencies, leads to an "apocalyptic millennialism" in Martha Lee (1995:140). James Lovelock (2006) sees it inevitable to go to the Eocene and the quagmire in which we find ourselves is not because of stupidity and ignorance but, on the contrary, because of our intelligence and creativity. They accuse the infrastructures of Christianity and humanism, that man is the greatest threat to Gaia (Lovelock, 2006).

This something not shared by Vladimir I. Vernadsky, Max Scheler, Edmund Husserl, etc., Colin Wilson (1931-2013) writes "never before in history has humanity had such a depressing view of itself" (quote Lachman, 2017). Original sin is the excessiveness and arrogance with which man transcends animal consciousness. Jorge Riechmann (2017.159) proposes, instead of "let's celebrate what we are": "let's land rather than we are!". In the following points we will discuss the problem of evil (3.1), our role as repairers of the cosmos (3.2) and the plausibility of geophysiology (3.3).

\section{What's after the Anthropocene?}

"Sustainable development" is gaining detractors. James Lovelock (2006) believes that we must abandon "sustainable development" in favor of "sustainable withdrawal". It is a thesis of James Lovelock, John Gray and others. The time for "sustainable development" is over. The original sin is in not accepting our guilt, finitude, contingency, etc. We are not in the context of a scientific discussion on climate change, but of anthropological and theological approaches. The earth is sick of humanity: a plague is not an argument, it is an assertion of pathological pessimism.

In the same vein as James Lovelock (2006) is expressed Edward O. Wilson (1929-) (2016) who sees man as a tribal carnivore willing to kill on behalf of his tribe. Never before has humanity had such depressing visions of itself. It is not a question of humanity following frivolous currents of thought that deny science. What is affirmed is the great failure of what we consider the most valuable: the capacity to learn (ÁlvarezPereira, 2019).

How do you support an orderly, planned, controlled 'sustainable withdrawal' etc., and instead for 'sustainable development' is there no time? From the Anthropocene, we will not go to Holocene but to the Eocene shredder: a planet with a temperature increase of 7 degrees (Lovelock, 2008). 


\subsection{Morphology}

Earth has its own geophysiology, which has kept the planet fit for life for more than three billion years. Self-regulation is a process that we are only beginning to intuit. The current global ecological crisis is due to the incomprehension of geophysiology.

The Anthropocene begins in the 18th century. At that time in the West the human being was freed from a double prison; on the one hand, of the ecclesiastical authorities, and on the other hand, of the absolutist State. Man emancipated himself from theological dogmas and normative dogmas. Science and technological innovations were rushed. All this was based on three concepts: grow, accelerate and condense (Rosa, 2013). Three centuries later, warns the Club of Rome (Weizsäcker, Wijkman, 2019), we can no longer be blind to the many weaknesses of a reductionist analytic philosophy, a dogmatic science, a daring market and an arrogant technology. Here Ortega y Gasset (2014.158) reminds us of human life "is not only a struggle with matter, but also man's struggle with his soul."

The ambivalence of modernity is not new. It was highlighted by Karl Marx, while he praised the revolutionary role of the bourgeoisie in 1848: "the bourgeoisie cannot exist without permanently revolutionizing the instruments of production, and with it, social relations". It is also quoted by Jürgen Habermas (1968) in a sense, perhaps opposite or, at least, without the optimism of the revolutionaries of a century and a half ago.

This revolutionary character of the "productive forces" is not due to planned action. We do not have the rationality with respect to the ends, but a "passive adaptation"; institutional frameworks do not set normative limits to technological development when it conflicts with fundamental rights, but have the capacity to modify moral rules of the game and our ethical understanding as a species (Habermas, 2001). It involves autonomous dynamics that, at some point out Ray Kurzweil, surpass man, at which point innovation intensifies its speed (Weizsäcker, Witjman, 2019).

\subsection{Progress and the dark side of history}

The Anthropocene refers to more than just altering the social relations of production. Technological acceleration is altering the moral foundations of modernity and our own self-understanding as a species. Jürgen Habermas points out that science and technology become technocratic consciousness, on the one hand, and, on the other hand (a century after the words of Karl Marx) science assumes the role of bourgeois ideology destroyed by the innovative dynamics themselves (Habermas, 1968). Here we find the equivocal concept of rationality as they point out, a century ago in the "Dialektik der Aufklarung" Theodor W. Adorno (1903-1969) and Max Horkheimer (1895-1973) (1997). We should add the radicalized criticism of Herbert Marcuse (1898-1979). Scientific and technical progress involves not only the destruction of social relations and institutional frameworks, but also the destruction of the planet and the human substance (Marcuse, 1954).

For Ulrich Beck the words of Karl Marx and Friedrich Engels written in 1948 could be subscribed by any neoliberal of the late 20 th century (Beck, 1997: 48). The capacity of domination and control of the productive forces over nature and society has its own meaning to that contained in Karl Marx's statement. Modernization and progress itself displace the foundations and coordinates of modernity itself and, consequently, capitalism becomes a gravedigger of capitalism itself (Beck, 1993). 
The fusion of the biotechnology, bioengineering and infotechnology revolution will allow us to move from manipulating the "outer world" to manipulating the "inner world". Man, from the seventeenth century, conquered an enormous power to manipulate the "outside world". The result of that is the current "ecological collapse" for not having understood the complexity of global ecology (López Ortega, et. al., 2021:166). In the 21 th century we are gaining the power to manipulate the inner world without having the slightest idea of how it works. It opens up terrifying narratives and mink of the future like those promoted by Ray Kurzweil (Weizsäcker, Wijkman, 2019).

\subsection{The role of the observer}

Man occupies an eccentric place. It becomes a geological force and, at the same time, is expelled from the cosmos, from knowledge and from history. The image of the modern "world of science" was purged from the subjective images of the "world of life" (Habermas, 2012). There is a paradoxical situation between the social sciences and the human sciences; Carl Gustav Jung (1875-1961) (2019:205) criticizes that the humanities prefer to avoid the audacious attempt to enter the unknown, the invisible, while physics, to enable a certain problem to be more or less fruitful, unfolds in an apparent "contradictio in adiecto".

Galileo (1564-1642) was aware that modern science is not a compendium of knowledge of the world when he asserts "mente concipio", that is, "I conceive it in my mind" (Gadamer, 1993). The theory of relativity dethrones Euclidean geometry. Galileo and Newton made the universe Euclidean. Because reason dictated it (Ortega y Gasset, 1938:153). There is a rational anthropocentrism: forcing nature to behave rationally and adopting the rational point of view: "sub specie aeternitatis" (Ortega y Gasset, 1938:148). Albert Einstein (1879-1955) understands that the distance of two objects belongs to the objects themselves: there is no space apart from physical objects There is no matter without form and observation without an observer. Time becomes a fourth dimension. It is not a thesis but to conceive a model by the observer (Jung, 2019.205). "In the cosmic spectacle" says José Ortega y Gasset (1939:149) "there is no spectator if locality". In the Anthropocene, pure reason cannot walk without going hand in hand with experience.

Manuel Arias-Maldonado $(2015: 18,24,42)$ reminds us that natural history is also social history. Science and ecology have renounced historical consciousness and, therefore, also utopia. We are surrounded by dystopias and apocalyptic hypotheses based on reckless speculation. In opposition, we have the thesis of the end of science; or, at least, as Jeremy Baski (2015) points out, what until now we understood by thinking in scientific terms: dualistic, binary and, therefore, exclusive. We go back to the romantic thought of J.G. Herder (1744-1802) and J.W. Goethe (1749-1832) passing through Alexander Humboldt (1769-1859). Buddha front with a negative assessment of life Christianity, what is wanted, is to return to the spiritual world from which it has fallen, Christianity does not disdain the earthly: for the Buddhist there is no way of salvation only of flight, for the Christian there is the way of bliss: the immanent lacks value, only the capacity for transmutation expressed at the Last Supper has value. Life is a training for death (Ortega y Gasset, 1938:64). Here that man, says José Ortega y Gasset (2014:85) is "at a natural and supernatural time, a kind of ontological centaur"; body and soul are things, whereas man is neither one nor the other, but "a drama, and a struggle to become what it has to be" (2014:87). The scientific revolution, with a nature that rests on the absence of human footprints, is challenged (Arias Maldonado: 2014). 


\section{Conclusions}

"What we observe", notes Werner Heisenberg (1901-1976), "is not nature in itself, but nature exposed to our method of questioning" (quoted by Capra,1996). For Werner Heisenberg (1979) since I. Sir. Newton, science has sacrificed the "living and immediate understanding of nature".

In this idea is present the criticism of J.W. Goethe to I. Sir Newton. The Anthropocene poses a new nosology. This places us in an argument far from the one that insists on the natural limits to growth or the call to curb capitalism - an issue that focuses on environmentalism (Arias Maldonado, 2017:321). But we have also not tried to provide evidence of man's geological impact on earth. Jeremy Baskin (2015) warns us of the risk of deepening "the depoliticization of society". It warns of the consequences of the expansion of technocratic consciousness which would have the effect of reducing the political to the technical. We are committed to a fruitful and respectful dialogue between natural and social sciences (Arias Maldonado, 2017: 322).

Climatologists have had the leading voice in the climate crisis, while anthropologists and sociologists have had only a marginal voice. Environmentalists have found a horror story in the offered description of climate change. Jorge Riechmann (2017.261) speaks of "cosmic pessimism". The question is whether the bridge between "the facts" and claiming that "we live in hell" is strong. Donna J. Haraway (1944-) (2016) assembles biology, ecology, feminism and science fiction. Environmentalists are comfortable with Dona Haraway's "Capitalocene" (2015). Manuel Arias-Maldonado (2015: 44) warns us of the unifying element of environmentalism: the rejection of anthropocentrism.

Harald Welzer (2008.211) warns us that some questions may be mis repaired. At what point do human technologies increase carrying capacity above regeneration capacity? Catastrophe begins when no one notices that what is being done is destructive. It is a normative response to descriptive responses. Science, without the frames of reference studied by sociology, ends up defending conservationist postulates. Edward O. Wilson (2016) does not lead us to a cognitive change, its solution is to leave a part of the planet. Climate change does not act on an amorphous social body. Climate change reveals social pathologies and dysfunctions, that is, the backstage of society (hinterbühne der Gesellschaft) (Welzer, 2008:43).

The Rwandan genocide, described in purely climatic terms, is a "linguistic coverup" (Welzer, 2008:88-89). In the Anthropocene, it is refused that science pretends to understand the epidermis of the earth, the earth's crust, without considering life. We live in an anthropomorphic land: it adapts for us to live in. The academic ecologist thinks that if man destroys his habitat worse for him and better for nature; the centuries needed for trees to bear fruit are opposed to how quickly they become edges again and bear no fruit. Decoupling geology and anthropology have led us to set human reason against the wisdom of nature.

Funding: This research received no external funding.

Institutional Review Board Statement: Not applicable.

Informed Consent Statement: Not applicable.

Acknowledgments: 
Conflicts of Interest: The author declares no conflict of interest.

\section{References}

Aanen, D.R.; Eggleton, P. 2017. Symbiogenesis: Beyond the endosymbiosis theory? Journal of Theoretical Biology, 434 (7): 99-103. https://doi.org/10.1016/j.jtbi.2017.08.001

Álvarez Pereira, C. 2019. Reflexionar sobre cómo reflexionamos. In Come on! Capitalismo, cortoplacismo, población y destrucción del planeta. Weizsäcker, E.U.; Wijkman, A. Barcelona: Deusto, pp. 206-210.

Arias-Maldonado, M. 2014. Antropoceno: el fin de la naturaleza. Revista de Libros.

Arias-Maldonado, M. 2015. Environment and Society. Socionatural Relations in the Anthropocene. New York, Dordrecht, London: Springer.

Arias-Maldonado, M. 2016. El giro antropocénico. Sociedad y medio ambiente en la era global. Política y Sociedad, 53 (3): 795-814. DOI:10.5209/rev_POSO.2016.v53.n3.49508

Arias-Maldonado, M. 2017. Antropoceno sin Antropoceno. Eunomía. Revista en Cultura de la Legalidad. 13.:321-326. https://doi.org/10.20318/eunomia.2017.3827

Arias-Maldonado, M. 2018. Science or Fiction? What the Anthropocene Means for EPT. Science and Environmental Political Theory. WPSA, Sant Francisco.

Arias-Maldonado, M. 2018a. Antropoceno: La política en la era humana. Barcelona: Taurus/Penguin Random Huse.

Baskin, J. 2015. Paradigm dressed as epoch. Environmental Values, 24, 1:9-29. DOI: 10.3197/096327115X14183182353746

Beck, U. 1988. Gegengifte: Die organisierte Unverantwortlichkeit. Frankfurt a M.: Suhrkamp.

Beck, U. 1997. Was ist Globalisierung? Irrtümer, des Globalismus -Antwortung aud Globalisierung. Frankfurt a M.: Suhrkamp. Beck, U. 2014. Emancipatory catastrophism: What does it mean to climate change and risk society? Current Sociology, 63, Issue 1:75-88. https://doi.org/10.1177/0011392114559951

Beck, U. 2016. The Metamorphosis of the World. How Climate Change is Transforming Our Concept of the World. Cambridge: Polity Press.

Beck, U. 1988. Gegengifte: die organisierte Unverantwortlichkeit. Frankfurt a M. Suhrkamp..

Benjamin, W. 1980. Über den Begriff der Geschichte. In. Gesammelte Schrifte, I-2: Frankfurt a M.: Suhrkamp. pp. 691-704. Berg, R. 1930. Die Grundlagen einer richtigen Ernährung. Deutscher Verlag für volkswohlfahrt, Dresde.

Castells, M. 2009. The Information Age. Economy, Society and Culture: A Summary: II. The Power of Identity. Blackwell, Oxford, Malden, MA.

Crutzen, P. J.; Stoermer, E.F. 2000. The 'Anthropocene'. GlobalChange Newsletter, 41:17-18.

Duarte, C.; Pardo, M.; y otros 2006. Cambio Global. Impacto de la Actividad Humana sobre el Sistema Tierra. Madrid: CSIC.

EU Agricultural. 2019. Fertilizers in the EU. Prices, trade and use. Agricultural Markets Briefs, 15.

Fechner, G.T. 2011. Einige Ideen zur Schöpfungs- und Entwicklungsgeschichte der Organisme. 1873. Hamburg: Tredition Clasics.

Foster, J.B.; Clark, B. 2018. The Robbery of Nature. Capitalism and the Metabolic Rift. Monthly Review. DOI: https://doi.org/10.14452/MR-070-03-2018-07_1

Foster, J.B. 2000. Marx's Ecology. Materialism and nature. New York: Monthly Review Press.

Furukawa, Y.; Chikaraishi, Y, et a 2019) Extraterrestrial ribose and other sugars in primitive meteorites". PNAS, 111 (49): 24.440-24.445. DOI: 10.1073 / pnas.1907169116

Gadamer, H-G. 1993. Über die Verborgenheit der Gesundheit. Frankfurt a M. Suhrkamp.

Garrood, W., et a 2021. Analysis of off-target effects in CRISPR-based gene drives in the human malaria mosquito. PNAS. DOI: 10.1073 / pnas.2004838117 
Gates, B. 2021. How to Avoid a Climate Disaster: The Solutions We Have and the Breakthroughs We Need. New York. Alfred A. Knopf.

Goethe, J.W. 1982. Schriften zur Naturwissenschaft. Stuttgart: Reclam. First published 1793.

Gray, J. 2003. Straw Dogs: Thoughts on Humans and Other Animals. London: Grata Books.

Gray, J. 2015. The Soul of the Marionette: A Short Inquiry into Human Freedom. New York: Farrar, Strau and Giroux. Habermas, J. 1963. Theorie und Praxis. Sozialphilosophische Studien. Frankfurt a M. Suhrkamp.

Habermas, J. 2001. Die Zukunft der menschlichen natur. Auf dem Weg zu einer liberale Eugenik? Frankfurt a M. Suhrkamp. Habermas, J. 2006. Political Communication in Media Society: Does Democracy Still Enjoy an Epistemic Dimension? The Impact of Normative Theory on Empirical Research. Communition Theory, 16 (4): 411-426. DOI: 10.1111 / j.14682885.2006.00280.x

Habermas, J. 2011. Das Unbehagen an der politisch-medialen Klasse. Sueddeutsche, 7.4.2011,

Habermas, J. 2012. Nachmetaphysischen Denken II. Aufsätze und Repliken. Frankfurt a M.: Suhrkamp.

Habermas, J. 2013. Im Sag der Technokraftie. Klein Schriften XII. Frankfurt a M.: Suhrkampt.

Habermas, J. 2019. Auch eine Geschichte der Philosophie - Band 1: Die okzidentale Konstellation von Glauben und Wissen. Frankfurt a M.: Suhrkamp.

Habermas, J. 1968. Technik und Wissenscghaft als "Ideologie"? Klassenkampf und Ideologie heute. Markur, 244: 682693.

Hamilton, C. 2016. The Anthropocene as rupture. The Anthropocene Review, 2 (1): 59-72. https://doi.org/10.1177/2053019616634741

Harari, Y.N. 2018. 21 Lessons for the 21st Century. London: Jonathan Cape.

Harawey, D. 2016. Staying with the trouble: making kin in the Chthulucene. Duke: Duke University Press.

Haraway, D. 2015. Anthropocene, Capitalocene, Plantationocene, Chthulucene: Making Kin. Environmental Humanities, 6: 159-165.

Heidegger, M. 1961. Nietzsche II. 1939-1941. Suttgart: Neske.

Heine, H.. 1969-1976. Sämtlichen Schriften. Munich: Hanser.

Horkeimer, M. 1997. Gesammelte Schriften, Band 5. 1940-1960. Frankfurt a M. Fischer.

Horton, R. 2020. COVID-19 is not a pandemic. The Lancet, 396 (10255):874.

IAASTD. 2009. Agricultures at a Crossroads. Washington: Island Press.

IPCC. 2019. Climate Change and Land. An IPCC Special Report on climate change, desertification, and degradation, sustainable land management, food security, and greenhouse gas fluxes in terrestrial ecosystems.

Jones, N. 2011. The human epoch. Nature, 473, 133. https://doi.org/10.1038/473133a

Jung, C.G. 2019. Von den Wurzeln des Bewutseins. 1934. Oltern: Walter-Verlag.

Kemp, L. 2021. 'Stomp Reflex': When governments abuse emergency powers. BBC, 28.4.2021.

Kirchfeld, F.; Boyle, W. (1994) Nature doctors: pioneers in naturopathic medicine. Medicina Biologica. Portland/ Oregon/ Ohio: Buckeye Naturopathic Press.

Lachman, G. 2013. The Caretakers of the Cosmos: Living Responsibly in an Unfinished World. Edimburg: Floris Book.

Lachman, G. 2017. Lost Knowledge of the Imagination. Edimburg: Floris Books.

Lee, M. 1995. Earth First! Environmental Apocalypse. New York. Syracuse University Press.

Lehman, R.M. et al. 2015. Understanding and Enhancing Soil Biological Health: The Solution for Reversing Soil Degradation. Sostenibilidad 7 (1): 988-1027. https://doi.org/10.3390/su7010988

Lenton, T.M.; et. al. 2020. Life on Earth is hard to spot. The Anthropocene Review, 7 (3):248-272. https://doi.org/10.1177/2053019620918939 
López Ortega, J., et. al. 2021. Economía circular: Nuevas formas de pensar y actuar en un territorio socialmente sostenible y responsable (TS2R). In Economía circular: fundamentos y aplicaciones. Meseger Sánchez, J.V., y otros (ed.). Navarra: Aranzadi-Thomas Routers, pp. 159-178.

Lovelock, J. 2006. The revenge of Gaia: Earth's Climate Crisis and the Fate of Humanity. New York: Basic Book.

Lovelock, J. 1991. Healing Gaia: Practical Medicine for the Planet. New York. Harmony.

Lovelock, J. 2008. Medicine for a feverish planet: kill or cure? The Guardian, 1.9.2008.

Lovelock, J.; Margulis, L. 1974. Atmospheric homeostasis by and for the biosphere: the gaia hypothesis. Tellus, 26 (12):2-10. https://doi.org/10.1111/j.2153-3490.1974.tb01946.x

Lovelock, J.; Margulis, L. 1974a. Biological modulation of the Earth's atmosphere. Icarus, 21(4): 471-489. DOI: 10.1016 / 0019-1035 (74) 90150-X

Lutz-Bachmann, M.; Fiora, A. 2008. Handlung und Wissenschaft-Action and Science. Berlin: Akademie Verlag.

Marcuse, H. 1954. One-dimensional man. Boston: Bacon Press.

Margulis, L. 1974. Five-Kingdom Classification and the Origin and Evolution of Cells. In Evolutionary Biology. Dobzhansky, T.; et al. (eds). New York: Plenum Press, pp: 45-78.

Margulis, L.; Sagan, D. 1986. Microcosmos. Four Billions Years of Evolution from Our Microbial Ancestors. Berkeley/ Los Angeles/ London: University of California Press.

Marx, K. 1985. Das Kapital: Kritik der politische Ökonomie, III. Berlin: Dietz Verlag. First published 1894.

Müller, D. 2020. Chemistry of the Climate System. Berlin: Walter de Gruyter GmbH \& Co KG.

Mulvaney, R.L.; Khan, S.A.; Ellsworth, T.R. 2009. Synthetic nitrogen fertilizers deplete soil nitrogen: a global dilemma for sustainable cereal production, J. Environ Qual, 38:2295-2314. DOI: 10.2134/jeq2008.0527

Munfort, L. 1971. The Myth of the Machine. Technics and human Development. New York: I. HBJ Book.

Naredo, J.M.; Valero, M. 1999. Desarrollo económico y deterioro ecológico. Visor, Madrid.

OCDE / FAO 2020. Perspectivas agrícolas 2020-2029. Roma, Paris: OCDE/FAO.

Ortega y Gasset 2019. Ideas y creencias y otros ensayos. Alianza editorial, Madrid. First published 1940.

Ortega y Gasset J. 1938. Temas de nuestro tiempo. Madrid: Espasa Calpe, Madrid.

Ortega y Gasset, J. 2014. Ensimismamiento y alteración. Meditación de la técnica y otros ensayos. Madrid: Alianza Editorial.. First published 1939.

Paracelsus, T. 1965. Medizinische Schriften. 1520-1570 (Will-Erich Peuckert) Werke I. Wissenschaft Buchges, Darmstadt. Pauli, G. 2021. From Data Mining to Data Farming - An internet model inspired by Nature (Part One), Rec News.

Peinado Lorca, M. 2019. Polvo de estrellas: de cómo la vida pudo caer del cielo. The Conversation.

Piulats, O. 2017. La ciencia espiritual de la naturaleza. Barcelona: Carena..

Piulats, O. 2018. Descubre la oculta naturaleza del mar. Barcelona: Carena.

Plessner, H. 1981. Die Stufen des Organischen. Gesammelte Schriften IV. Frankfurt a M. Suhrkamp. .

Riechmann, J. 2017. ¿Vivir como Buenos huérfanos? Ensayos sobre el sentido de la vida en el siglo de la Gran Prueba. Madrid: Catarata.

Rockström, J.; Steffen, W.; et al. 2009. A safe operating space for humanity. Nature, 461: $472-475$. https://doi.org/10.1038/461472a

Rosa, H. 2013. Beschleunigung und Entfremdung - Entwurf einer kritischen Theorie spätmoderner Zeitlichkeit. Frankfurt a M.: Suhrkamp.

Schmutzer, M.; Wagner, A. 2020. Gene expression noise can promote the fixation of beneficial mutations in fluctuating environments. PLoS Computational Biology, 16(10):1-24. 
Steffen, W.; Crutzen, P.; McNeill, J. R. 2007. The Anthropocene: Are Humans Now Overwhelming the Great Forces of Nature?. Ambio, 36 (8): 614-621.

Steiner, R. 1990. Goethes Weltanschauung. GA 6. Dornach: RSV. First published 1897.

Steiner, R. 2010. Einleitungen zur Goethes Naturwissenschaft (1883-1897). GA 1. Dornach: RSOV.

Steiner, R. 2010a. Geisteswissenschaftliche Grundlagen zum Gedeihen der Landwirtschaft. GA 327. Dornach: RSOA. First published 1924.

Stoermer, E.F. 1984. Research on Great Lakes Algal Communities: Problems from the Past, Lessons for the Future. Journal of Great Lakes Research, 10 (2): 143-155. https://doi.org/10.1016/S0380-1330(84)71821-1

Suess, E. 1875. Die Entstehung der Alpen. Wein: Wilhelm Braummuller..

Valero, A. 2019. Materiales: Más allá del cambio climático. In Come on! Capitalismo, cortoplacismo, población y destrucción del planeta. Weizsäcker, E.U.; Wijkman, A. Barcelona: Deusto, pp. 206-210.

Vernadsky, V.I. 1998. The Biosphere. New York: Copernicus. First published 1926.

Weizsäcker, E.U. von, Wijkman, A. 2018. Come on! Capitalism, Short-termism, Population and the Destruction of the Planet. Springer, New York.

Welzer, H. 2008. Klimakriege. Wofür im 21. Jahrhunder getötet wird. S. Fischer, Frankfurt a M

Wilson, E. O. 2016. Half-Earth: Our Planet's Fight for Life. New York: Liveright. 